\title{
The Journal of Southeast Asian Studies: Retrospect and Prospect
}

With this issue, the Journal of Southeast Asian Studies (JSEAS) celebrates twenty years of publication, and turns twenty-one this month. Of course, it was not created ex nihilo but was the direct successor of the Journal of Southeast Asian History (March 1960 to December 1969), and it represented recognition of the already broadening scope of articles being published in its predecessor. The first issue of the $J S E A S$ set forth both the connexion between the two Journals, and the rationale for the new Journal:

This is a reorganized format of the Journal of Southeast Asian History. Since the latter's appearance in 1960 , it has developed into a publication of international stature, providing an outlet for scholarly contributions on the history of the region. More recently, the Journal has also published articles from allied disciplines, especially the social sciences, in the belief that multi-disciplinary approaches will deepen and enrich our understanding of Southeast Asia. In changing the title to the Journal of Southeast Asian Studies, this new orientation is given formal recognition.

Apart from the change of title, there was also a change of publishers and distributors (from the History Department, University of Singapore, and MPH Distributors, to McGraw-Hill Far Eastern Publishers) and of format. However, the Journal continued to be firmly based at the History Department, with the Head or Acting Head of Department remaining Chairman of the Editorial Board and departmental staff providing the main editorial back-up with the assistance of Faculty colleagues.

It would be appropriate at this juncture to express my deep appreciation to the two Raffles Professors of History (Dr K.G. Tregonning and the late Professor Wong Lin Ken) who founded the two Journals, and to the host of contributors, readers, referees, reviewers, editorial board and advisory committee and corresponding members, and our publishers (both McGraw-Hill FEP and currently Singapore University Press) for their varied and valued contributions to the high scholarly reputation of the $J S E A S$.

In retrospect it is clear that both Journals have been beneficiaries as well as disseminators of significant scholarly advances in Southeast Asian Studies in the past three decades. In historical scholarship, I concur in the opinion of the first Editor of JSEAS, Associate Professor R. Suntharalingam (now at the Universiti Sains Malaysia) that the Journals "mark a turning point in Southeast Asian historiography, ending what might be loosely termed the era of 'colonial historiography' and the assertion of "nationalist historiography'" (private communication, 15 February 1990). In the 1960s the issues of autonomous or Asia-centric versus Euro-centric history surfaced in the pages of the $J S E A H$, and since then other views and interpretations have been debated in the pages of the JSEAS. From its inception, the Journal has 
never been averse to the free expression and play of ideas, and resultant controversy, and as we enter into the 1990s it retains this openness. We reaffirm the statement in the first issue: "The editorial policy of the Journal avoids commitment to any ideology, view point, or interpretation, which are solely the responsibilities of the contributors."

Over the past two decades, the $J S E A S$ has of course not remained static. We have followed the practice of other established journals in including abstracts of articles, and imprinting the volume and number of each issue on the masthead of each article. In our review section, we have initiated reviews of publications in Southeast Asian languages. Where appropriate, we intend to revive our past practice of having Special Issues on select themes. As recently announced, we have started a new Special Publications Series to accommodate monographs and collections of symposium papers of between 30,000 and 50,000 words in length. The first title in this series, introduced and translated by Benjamin Batson and Shimizu Hajime, and entitled The Tragedy of Wanit, will be published later this year. We shall also be publishing a comprehensive Index to both the JSEAH and the JSEAS for 1960-89.

As we enter the last decade of this century, with the vast changes that are taking place in the region as well as around the world, the Journal will strive to fulfil its mission of facilitating scholarly discussion and debate of various topics and issues of Southeast Asian studies. In doing this, we are acutely aware that we are dependent on our contributors for the articles, reviews and reports which will stimulate such discussion and debate. On our part, we undertake to maintain the high professional standards of evaluation, editing and publication which our contributors deserve and expect.

Ernest C.T. Chew

Chairman

JSEAS Editorial Board 